\title{
Bangla Translations of Latin American Poetry: A Critical Study
}

\author{
Ranita Chakraborty Dasgupta, PhD \\ (D)/0000-0001-6173-0216
}

Assistant Professor, Amity Institute of English Studies and Research, Amity

University, Kolkata

DOI: $h t t p s: / / d x . d o i . o r g / 10.46679 / 978819484830103$

The aim of this study is to map the reception of Latin American Poetry within the corpus of the Bangla world of letters for three decades, from 1980 to 2010. In the 1970s and the 1980s, the influence and reception of Latin American Literatures in Bangla was reflected primarily in the introductions to translations, preludes, and conclusions of translations. During the late 1960s and the early 1970s Latin American poets like Pablo Neruda, Victoria Ocampo, Octavio Paz, and Jorge Luis Borges had caught the attention of eminent Bangla poets like Bishnu Dey, Shakti Chattopadhyay, and Shankha Ghosh who started taking interest in their works. This interest soon got reflected in the form of translations being produced in Bangla from the English versions available. The next two decades saw the corpus of Latin American Literatures make a widespread entry into the world of academic essays, journals, and articles published in little magazines along with translations of novels, short stories and poetry collections by leading Bangla publication houses like Dey's Publishing, Radical Impressions, etc. This period was marked by a proliferation of scholarship in Bangla on Latin American Literatures. By the 21st century, critical thinking in Latin American Literatures had established itself in the Bangla world of letters.

This chapter in particular studies the translations of Latin American poetry by Bengali poets like Shakti Chattopadhyay, Subhas Mukhopadhyay, Bishnu Dey, Buddhadeb Bhattacharya, Shankha Ghosh, Biplab Majhi among many others. The analysis relates to issues they 
focus on including themes like self, modernity, extension of time and space, political and poetic resonances, and untranslatability. Through a step by step research of the various stages of translation activities in Bengal and Bangla, it traces how translations of Latin American Literatures begin to take place on literary grounds that had already become sites of engagement with these issues.

The chapter further explores the ways in which all these poettranslators situate their translations in relation to the issues of concern. In addition, it also addresses the question of what they hence contribute to Bangla literature at large. I first chose to explore the ways in which these issues are framed in the reflections and debates on translation in India and Bengal in the 20th century. Thereon I have tried to show how these translations of Latin American poetry developed their own thrust in relation to these issues and concerns.

\section{Translation in India in the $20^{\text {th }}$ Century}

By the end of the $19^{\text {th }}$ century, India saw the intrusion of English into the subcontinental consciousness re-affirming its hegemonic status over all Indian languages. This is made possible by the reinforcement of political and administrative pressures. According to Avadesh K. Singh and Asaduddin, on studying the trajectory of translations at this point of time one can locate a shift in focus from the Persian-centric literary culture to an English-centric one. With colonialism, the Indian subcontinent entered a phase that demanded a different conceptualization of translation. For Anglicists and Orientalists translating India into their respective languages was a way of re-inventing it according to their own models. As Asaduddin correctly puts it,

Colonialism was a colossal project of translation where human beings and not texts became the object of translation. ...the project of colonial modernity was made possible by translation. Soon there emerged a section of writers and intellectuals who can truly be 


\section{This is a limited preview of the chapter.}

To read the full-text chapter, get access by purchasing this chapter or consider buying the complete book. If your library has subscription to EBSCOhost, the chapter including other chapters of the book can be accessed through your library.

This chapter is a part of the book, 'Contemporary Translation Studies' ISBN (paperback): 978-81-948483-0-1; ISBN (ebook): 978-81-948483-8-7

Book DOI: https://dx.doi.org/10.46679/9788194848301 
readership through the translations of Buddhadeb Bhattacharya in Chena Fuler Gandha: Ek Guchcha Bideshi Kabita, the universal consciousness of class struggle and the fight for liberation seen in the translation of Fernando Gordillo Cervantes's poetry by Bhattacharya again in the same edition, love and reverence for the political hero, class struggle in the face of capitalist exploitation and a political elegy in Bishnu Dey's translation of Jacinto Fombona Pachano published in Tumi Robe Ki Bideshini. In the same edition, the Bangla readership also came across Nicolas Guillen and Jose Marti and their poems voicing anti-capitalism, structures of exploitative power, expression of global solidarity, social discrimination, political change, and universal brotherhood.

The final mention here would be that of another unique strand of Bangla translations of Latin American Literatures where the receiving readership saw translations like American Indian Sreshtha Kabita. This was a volume that only introduced Bangla readers to a culturally rich body of folk traditions but also became emblematic of the act of archiving of rich oral literature that characterized almost all the Native American communities.

In conclusion, these are some of the strands of translation thematic along which the Bangla readership received the Latin American Poetry during the three decades, from 1980 to 2010.

\section{Bibliography and Citations}

\section{Books}

Bhattacharya, Buddhadeb, trans. 1984.Chena Ful-er Gandhya: Ek Guchcha Bidheshi Kobita. Kolkata: Dey's Publishing. Chattopadhyay, Shakti, Mukul Guha, trans. 1992. American Indian Srestha Kobita. Kolkata: Dey's Publishing. (Also contains a joint Introduction by both the translators) 
De, Bishnu, trans. 2007.Tumi rabe ki Bidheshini: Bishnu De krita Bideshi Kobita-r Anubad Samagra. Kolkata: Dey's Publishing. (Also contains an Introduction by Bishnu De)

Neruda, Pablo. 2010.Latin America-r Kobi o Kobita: Pablo Neruda. Translated by Biplab Majhi.Kolkata: Anjali Publishers. (Contains a vivid Translator's Introduction)

Neruda, Pablo. 1976.Pablo Neruda-r Premer Kobita. Translated by Shakti Chattopadhyay. Kolkata: Dey's Publishing.

Neruda, Pablo. 1988.Pablo Neruda-r Srestho Kobita. Translated by Shakti Chattopadhyay. Kolkata: Dey's Publishing.

Neruda, Pablo. 1972.Pablo Neruda-r Kobita. Translated by Mangalacharan Chattopadhyay. Kolkata: Sharshwata Library. (Contains Introductions to the First and Third Editions by the translator).

Neruda, Pablo. 1994.Nirbachita Pablo Neruda. Translated by Shubhash Mukhopadhyay. Kolkata: Dey's Publishing. (Contains a very short Translator's Note)

Parra, Nicanor. 1992.Nicanor Parra-r Srestha Kobita o Prati-Kobita. Translated by Manabendra Bandyopadhyay. Kolkata: Dey's Publishing. (Contains a Translator's Note and an Introduction)

Paz, Octavio. 2010. Latin America-r Kobi o Kobita: Octavio Paz. Translated by Biplab Majhi.Kolkata: Anjali Publishers. (Contains a vivid Translator's Introduction)

Paz, Octavio. 2008. Octavio Paz: Panchash-ti Kobita . Edited by Aveek Majumdar and Dibyajyoti Mukhopadhyay. Kolkata: Embassy of Mexico, New Delhi and Indo Hispanic Library. (Contains an Introduction by Mexican Poet Elsa Cross)

Ray, Asesh. 2007.Latin America...Ek Najar-e. Kolkata: Codex.

Talukdar, Purushottam, trans. El-Salvadorer Kobita. Kolkata: Codex. 


\section{Journals}

El Camino. Vol. III. 1999. Kolkata: Institute of Spanish Studies. La Cultura Hispanica. $2^{\text {nd }}$ Issue. January 2009. Kolkata: Codex. La Cultura Hispanica. 3rd Issue. July 2009. Kolkata: Codex. La Cultura Hispanica. 4th Issue. May 2010. Kolkata: Codex. Tibra Kutthar: Bishesh Shonkha. Boimela Volume IV. 2005. Kolkata: Ebong Mushyra.

\section{Academic essays in Bangla}

Pal, Rabin. 2007. "Daisy Samorar Kobita." Yugalbandi Spainiyo o Bharatiya Sahityo. January: 174-191.

Pal, Rabin. 2007. "Gabriela Mistraler Rabindranath: Ek Anjla." Yugalbandi Spainiyo o Bharatiya Sahityo.January: 106-112.

Pal, Rabin. 2007. "Jose Marti: Buddhijibir Bhumika." Yugalbandi Spainiyo o Bharatiya Sahityo. January: 94-105.

Pal, Rabin. 2007. "Octavio Paz: Kobi o Kobita Prosonge." Yugalbandi Spainiyo o Bharatiya Sahityo. January: 147-162.

Pal, Rabin. 2007. "Rabindranath o Pablo Neruda." Yugalbandi Spainiyo o Bharatiya Sahityo.January: 139-146.

Pal, Rabin. 2009. "Chile-r Kobita: Goto koek doshoke." La Cultura Hispanica 3rd Edition, July: 73-77.

\section{Translated Interviews}

1. Neruda, Pablo. Interview with Rita Guerta.. Tibra Kutthar-Latin Americar Godyo Shahitya. Translated by Rabin Pal. Tibra Kutthar, 2005.

2. Paz, Octavio. Interview with MacAdam. Tibra Kutthar-Latin Americar Godyo Shahitya. Translated by Dipanjana Sharma and Topomon Ghosh. Tibra Kutthar, 2005. 


\section{Editor's Notes, Introductions and Translator's Notes (collected as part of Critical Academic Commentaries)}

Bhattacharya, Utpal. 2004. “Editor's Note." Pablo Neruda-r Kobita. Kolkata: Kabitirtha:1-3

Ghatak, Tarun. 2003. "Introduction." Frederico Garcia Lorca. Kolkata: People's Book Society: 1.

Talukdar, Purushottam. 2010. "Translator's Note." Tomar Ujjwal Aankhi (Spain o Latin America-r Kobita Sangraha). Kolkata: Codex: 1 .

\section{Secondary Bibliography}

Alauddin, Razu. "When Tagore and Borges crossed paths." http://archive.thedailystar.net/newDesign/newsdetails.php?nid=207452 (Accessed on 22 October 2011).

Asaduddin, M. "Translation and Indian Literature: Some Reflections." Translation Today Vol-3: 1\&2, March-October: 1-9

Bassnett, Susan. 1980.Translation Studies. London: Routledge

Benjamin, Walter. 1950. Illuminations: Essays and Reflections. London: Schocken

Bullock, Marcus \& Michael W. Jennings, edited. Walter Benjamin Selected Writings Volume I (1913-1926). Cambridge: The Belknap Press of Harvard University Press, 1996

Chanda, Rajat. "Rabindranath Tagore: Tagore in South America: Some Perspectives." http://academic.udayton.edu/monishchatterjee/tagore/chand a.html.(Accessed on 15 May 2014).

Dasgupta, Subha Chakraborty. "Texts on Translation and Translation norms in Bengal." Translation Today Vol-3: 1\&2, March-October: 162-173 
Dimitriu, Rodica. 2002. Theories and Practice of Translation. Iasi: Institutul European

Dutta, Sandip. 1993. Bangla Galpo-Kobita Andolan-er Tin Dashak. Kolkata: Radical Impressions.

Ghosh, Arun Kumar. Adhunik Bangla Kobitar Itihaas. Kolkata Newmark, Peter. 1988. A Textbook of Translation. Hemel Hempstead: Prentice Hall International Ltd.

Ramakrishnan, E.V. 2006.“Guest Editorial.” Translation Today Vol-III, CIIL: i-xii

"Translating Culture vs. Cultural Translation". The University of Iowa website.http://iwp.uiowa.edu/91st/vol4num1/translating-culture-vs-cultural-translation. (Accessed on 17 May 2014)

Zhongde, Liu. 1991. Ten Lectures on Literary Translation. Beijing: China Translation \& Publishing Corporation. 
